\title{
INFORMATION SEEKING BEHAVIOUR OF STUDENTS OF PHYSIOTHERAPY COLLEGE LIBRARIES IN KARNATAKA: A STUDY
}

\author{
ATMANAND G HOLEYANNAVAR ${ }^{1} \&$ DR. VINAYAK M BANKAPUR ${ }^{2}$ \\ ${ }^{I}$ Research Scholar, Department of Library and Information Science \\ Rani Channamma University, Belagavi, Karnataka, India \\ ${ }^{2}$ Associate Professor, Department of Library and Information Science \\ Rani Channamma University, Belagavi, Karnataka, India
}

\begin{abstract}
Information seeking behaviour is the human activities with respect to searching various sources, channels including use of that information. The purpose of study is proven the information seeking and behavior of physiotherapy college student the study adopted a survey method. Data were collected from 1037 out of 1200 students. A finding tells that guidance was needed for the student to seek the information and also other resources available in the library. The study shows that the student's positive side of seeking information in there course related information.

KEYWORDS: Information, Information Seeking Behavior, Bachelor of Physiotherapy, Physiotherapy Library \& Library Users and Resources
\end{abstract}

Received: Jul 05, 2017; Accepted: Jul 25, 2017; Published: Aug 07, 2017; Paper Id.: IJLSRAUG20175

\section{INTRODUCTION}

Information is a human product. It is an important resource that it contributes towards the development of a nation. It provides the core for the development of knowledge, the basis for innovations, the resources for informed citizenry and as a result, it becomes a key commodity for the progress of a society. The significance of information in national development, Wasserman (1991, p. 38) noted that "it is not an accident that the developed nations are those, in which, information products and services have been brought into being, and are widely exploited first in conventional forms and later through computer intervention."

Information is one such essential commodity next to food, shelter, water for human need. In the electronic age, information is capitalized as one very important source. The study of information seeking has become an important tool for managing the needs of the users.

\section{REVIEW OF LITERATURE}

Sakai et. Al (2008) conducted a study on the latest information-seeking Behavior among health care consumers in Japan and compared these Behaviors with those, recorded in similar surveys administered in Japan and the United States, after 2000. Evidence indicates that Japanese health care consumers are now proactively looking for health information. These consumers feel reassured by the information that they can access and would like to read clinical research in their native language.

Genius, Shelagh (2012) concentrated on information Behavior in a context, where medical evidence is 
clearly evolving (management of the menopause transition). This investigation discovered how women interact with and make sense of uncertain health information mediated by formal and informal sources. Findings revealed that four strategies were used to build a sense from health information, mediated by the many information sources, faced and opened on an everyday basis; women assumed analytic and experiential "postures"; they valued social contexts for learning and knowledge construction; information consistency was used as a heuristic representing accuracy and credibility; and an important feature of sense making was source das complementary.

\section{STATEMENT OF THE PROBLEM}

Human-being is involved in certain activities which are complex and interdependent. This phenomenon gives rise to increasing need for information from some potential sources that are known to them. The information needs of library users are varied in nature. They differ qualitatively, quantitatively and geographically. They also differ with regard to intellectual level, frequency and volume of information sources required. There are unlimited producers of information. Some of them are governmental organizations; others are non-governmental agencies, institutions and industrial firms. These entire agencies add to the phenomenal growth of volume and variety of information. College library is the major source of information for college students. However, the usage pattern, attitude and behavior of students at libraries vary among them and differ from college to college. This study focused on the information seeking behavior of college students studying in physiotherapy colleges in the state of Karnataka.

\section{SCOPE AND LIMITATION OF THE STUDY}

The scope of the study is confined to the Information Seeking Behavior of Students of Physiotherapy colleges in Karnataka, which are affiliated to Rajiv Gandhi University of Health Sciences Bangalore, Nitte, Yenepoya, and KLE Universities.

\section{OBJECTIVES}

The specific objectives of the study are,

- To study the purpose of information seeking by the students.

- To identify the impact of internet and E-Resources while seeking information by the students.

- To study the problems faced by the students while seeking information; and

- To suggest the strategies of improving the student's information seeking behavior activities.

\section{HYPOTHESES}

- Most of the respondents are seeking information for study purpose only

- Internet and E-resources have positive impact on study activities of the respondents while seeking information.

- Most of the respondents are facing problems while seeking the information.

\section{METHODOLOGY}

The research method followed in the present study was Survey method. The researcher distributed the questionnaires among Students, and requested to fill them up. Librarians of different Physiotherapy colleges were given 
several copies of the questionnaire and were requested to get them filled up by the students of their colleges.

In the present study, the data collected from the published sources and the questionnaire were evaluated and analyzed to find out the results. The data gathered was analyzed by using Statistical Package for Social Science (SPSS), and the output was checked and corrected for any typographical error.

Table 1: Distribution of Age-Wise

\begin{tabular}{|c|c|}
\hline Age Group (Years) & No. of Students \\
\hline $17-18$ & $161(15.53)$ \\
\hline $19-20$ & $447(43.11)$ \\
\hline $21-22$ & $290(27.97)$ \\
\hline $23-24$ & $95(9.16)$ \\
\hline $25-26$ & $44(4.24)$ \\
\hline Total & $\mathbf{1 0 3 7}(\mathbf{1 0 0 \%})$ \\
\hline
\end{tabular}

The students profile with age group wise distribution is given in Table 1.It is observed that the number of students i.e. 161(15.53) belong to the age group of 17-18 years. This is followed by 447 (43.11) of students in the age group of 1920 Years and 290 (27.97) in the age group of 21-22 years. Comparatively, lesser number of respondents belongs to higher age groups like 23-24 years 25-26 years.

Table 2: Distribution of Class Wise

\begin{tabular}{|c|c|c|c|}
\hline Sl. No & Class Wise & No. of Respondents & \% of the Respondents \\
\hline 1 & $1^{\text {st }}$ Year BPT & 315 & 30.38 \\
\hline 2 & $2^{\text {nd }}$ Year BPT & 299 & 28.83 \\
\hline 3 & $3^{\text {rd }}$ Year BPT & 179 & 17.26 \\
\hline 4 & $4^{\text {th }}$ Year BPT & 167 & 16.10 \\
\hline 5 & $1^{\text {st }}$ Year MPT & 46 & 4.44 \\
\hline 6 & $2^{\text {nd }}$ Year MPT & 31 & 2.99 \\
\hline & Total & $\mathbf{1 0 3 7}$ & $\mathbf{1 0 0 \%}$ \\
\hline
\end{tabular}

Table 2 shows the year wise distribution of respondents of physiotherapy colleges in Karnataka. Out of 1037 total respondents, the highest $315(30.38 \%)$ of them belongs to $1^{\text {st }}$ year physiotherapy students, whereas $299(28.83 \%)$ respondents belongs to $2^{\text {nd }}$ physiotherapy students and the respondents are from $3^{\text {rd }}$ physiotherapy students $179(17.26 \%)$. $167(16.10 \%)$ respondents belong to $4^{\text {th }}$ year physiotherapy students. $46(4.44 \%)$ and $31(2.99 \%)$ respondents belong to $1^{\text {st }}$ year MPT students and $2^{\text {nd }}$ MPT students, respectively.

Table 3 Library Resources Up-to-Date with Current Developments in Your Fields

\begin{tabular}{|c|c|c|c|c|c|}
\hline Seeking & BPT & MPT & Total & $\begin{array}{c}\text { Chi- } \\
\text { Square }\end{array}$ & P-Value \\
\hline Reading current issues of print journals/ magazine & $492(51.25)$ & $57(74.03)$ & $549(52.94)$ & 14.8420 & $0.0001 *$ \\
\hline Reading latest books in the field & $481(50.10)$ & $55(71.43)$ & $536(51.69)$ & 12.9810 & $0.0001 *$ \\
\hline Browsing current issues of electronic journals & $209(21.77)$ & $43(55.84)$ & $252(24.30)$ & 44.9880 & $0.0001 *$ \\
\hline Searching online databases & $391(40.73)$ & $54(70.13)$ & $445(42.91)$ & 25.1520 & $0.0001^{*}$ \\
\hline Browsing websites of companies/ organizations & $220(22.92)$ & $29(37.66)$ & $249(24.01)$ & 8.4950 & $0.0040 *$ \\
\hline Accessing e-books & $166(17.29)$ & $39(50.65)$ & $205(19.77)$ & 50.0100 & $0.0001 *$ \\
\hline E-mail alerts from publishers & $111(11.56)$ & $18(23.38)$ & $129(12.44)$ & 9.1340 & $0.0030 *$ \\
\hline $\begin{array}{l}\text { Through awareness services from library like CAS \& } \\
\text { SDI }\end{array}$ & $43(4.48)$ & $7(9.09)$ & $50(4.82)$ & 3.3040 & 0.0690 \\
\hline Interaction with other students and teachers & $439(45.73)$ & $50(64.94)$ & $489(47.16)$ & 10.5520 & $0.0010^{*}$ \\
\hline Attending conferences, workshops, etc. & $319(33.23)$ & $59(76.62)$ & $378(36.45)$ & 57.9460 & $0.0001 *$ \\
\hline Email discussion groups & $70(7.29)$ & $10(12.99)$ & $80(7.71)$ & 3.2480 & 0.0720 \\
\hline Any other & $7(0.73)$ & $1(1.30)$ & $8(0.77)$ & 0.3020 & 0.5830 \\
\hline
\end{tabular}


- Out of total 1037 students, 52.94\% students know about the Current Developments of Reading current issues of print journals/ magazine. Out of $52.94 \%$ students, $51.25 \%$ of BPT students and $74.03 \%$ of MPT students know about the Current Developments. The difference is found to be statistically significant (chi-square $=14.8420$, $\mathrm{p}=0.0001)$.

- The majority of 536students, 51.69\%know about the Current Developments Reading latest books in the field, in which $481(50.10 \%)$ of BPT students and 55 (71.43\%) of MPT students know about the Current Developments. The difference is found to be statistically significant (chi-square $=12.9810, \mathrm{p}=0.0001$ ). The other details are presented in Table 3.

Table 4: Purpose of Seeking Information

\begin{tabular}{|l|l|l|l|l|l|}
\hline \multicolumn{1}{|c|}{ Purpose } & \multicolumn{1}{c|}{ BPT } & \multicolumn{1}{c|}{ MPT } & \multicolumn{1}{c|}{ Total } & $\begin{array}{c}\text { Chi- } \\
\text { Square }\end{array}$ & \multicolumn{1}{c|}{ p-value } \\
\hline General awareness & $650(67.71)$ & $64(83.12)$ & $714(68.85)$ & 8.1970 & $0.0170^{*}$ \\
\hline Prepare the class notes & $765(79.69)$ & $61(79.22)$ & $826(79.65)$ & 0.0830 & 0.9590 \\
\hline Project work & $591(61.56)$ & $68(88.31)$ & $659(63.55)$ & 22.9240 & $0.0001^{*}$ \\
\hline Preparing answers to questions & $628(65.42)$ & $55(71.43)$ & $683(65.86)$ & 1.1460 & 0.2840 \\
\hline Reading/Thinking purpose & $551(57.40)$ & $56(72.73)$ & $607(58.53)$ & 7.2070 & $0.0270^{*}$ \\
\hline Workshop and seminar & $394(41.04)$ & $57(74.03)$ & $451(43.49)$ & 31.5560 & $0.0001^{*}$ \\
\hline Discussion and Recreation & $371(38.65)$ & $43(55.84)$ & $414(39.92)$ & 9.1790 & $0.0100^{*}$ \\
\hline Any other & $8(0.83)$ & $1(1.30)$ & $9(0.87)$ & 0.1790 & 0.6720 \\
\hline
\end{tabular}

- A total of 714 (68.85\%) students knows about Seek Information through General Awareness, in which, 650 $(67.71 \%)$ of BPT students and $64(83.12 \%)$ of MPT students know about the Seek Information. The difference is found to be statistically significant (chi-square $=8.1970, \mathrm{p}=0.0170$

- The majority of 826 respondents (79.65\%) know about the Seek Information, through Preparing the class notes, in which 765 (79.69\%) of BPT students and $61(79.22 \%)$ of MPT students know about the Seek Information. The difference is not found to be statistically significant (chi-square $=0.0830, \mathrm{p}=0.9590$ ). The other details are presented in Table 4.

Table 5: Hours Spent at the Library by the Respondents

\begin{tabular}{|c|c|c|c|c|c|c|c|c|c|c|}
\hline Q 16 & & & BPT & $\%$ & MPT & $\%$ & Total & $\%$ & $\begin{array}{l}\text { Chi- } \\
\text { Square }\end{array}$ & p-Value \\
\hline \multirow[t]{4}{*}{1} & \multirow{4}{*}{$\begin{array}{l}\text { Searching } \\
\text { journals/ } \\
\text { magazine }\end{array}$} & $<3 \mathrm{hrs}$ & 553 & 57.60 & 44 & 57.14 & 597 & 57.57 & 30.1370 & $0.0001^{*}$ \\
\hline & & 4-6hrs & 394 & 41.04 & 25 & 32.47 & 419 & 40.41 & & \\
\hline & & 7-9hrs & 7 & 0.73 & 4 & 5.19 & 11 & 1.06 & & \\
\hline & & $>10 \mathrm{hrs}$ & 6 & 0.63 & 4 & 5.19 & 10 & 0.96 & & \\
\hline \multirow[t]{4}{*}{2} & \multirow{4}{*}{$\begin{array}{l}\text { Searching } \\
\text { for books }\end{array}$} & $<3 \mathrm{hrs}$ & 575 & 59.90 & 47 & 61.04 & 622 & 59.98 & 0.3870 & 0.9430 \\
\hline & & 4-6hrs & 325 & 33.85 & 26 & 33.77 & 351 & 33.85 & & \\
\hline & & 7-9hrs & 37 & 3.85 & 3 & 3.90 & 40 & 3.86 & & \\
\hline & & $>10 \mathrm{hrs}$ & 23 & 2.40 & 1 & 1.30 & 24 & 2.31 & & \\
\hline \multirow[t]{4}{*}{3} & \multirow{4}{*}{$\begin{array}{l}\text { Interaction } \\
\text { with } \\
\text { friends/ } \\
\text { teachers }\end{array}$} & $<3 \mathrm{hrs}$ & 313 & 32.60 & 34 & 44.16 & 347 & 33.46 & 7.4290 & 0.0590 \\
\hline & & 4-6hrs & 491 & 51.15 & 36 & 46.75 & 527 & 50.82 & & \\
\hline & & $7-9 \mathrm{hrs}$ & 105 & 10.94 & 7 & 9.09 & 112 & 10.80 & & \\
\hline & & $>10 \mathrm{hrs}$ & 51 & 5.31 & 0 & 0.00 & 51 & 4.92 & & \\
\hline \multirow[t]{4}{*}{4} & \multirow{4}{*}{$\begin{array}{l}\text { Browsing } \\
\text { e- journals } \\
\text { on internet }\end{array}$} & $<3 \mathrm{hrs}$ & 321 & 33.44 & 36 & 46.75 & 357 & 34.43 & 12.3520 & $0.0060^{*}$ \\
\hline & & 4-6hrs & 568 & 59.17 & 32 & 41.56 & 600 & 57.86 & & \\
\hline & & $7-9 \mathrm{hrs}$ & 61 & 6.35 & 6 & 7.79 & 67 & 6.46 & & \\
\hline & & $>10 \mathrm{hrs}$ & 10 & 1.04 & 3 & 3.90 & 13 & 1.25 & & \\
\hline
\end{tabular}




\begin{tabular}{|c|c|c|c|c|c|c|c|c|c|c|}
\hline 5 & \multirow{4}{*}{$\begin{array}{l}\text { Searching } \\
\text { online } \\
\text { databases }\end{array}$} & $<3 \mathrm{hrs}$ & 311 & 32.40 & 40 & 51.95 & 351 & 33.85 & 24.7090 & $0.0001^{*}$ \\
\hline & & 4-6hrs & 587 & 61.15 & 29 & 37.66 & 616 & 59.40 & & \\
\hline & & 7-9hrs & 48 & 5.00 & 3 & 3.90 & 51 & 4.92 & & \\
\hline & & $>10 \mathrm{hrs}$ & 14 & 1.46 & 5 & 6.49 & 19 & 1.83 & & \\
\hline \multirow[t]{4}{*}{6} & \multirow{4}{*}{$\begin{array}{l}\text { Email } \\
\text { alerts, } \\
\text { correspond } \\
\text { ence }\end{array}$} & $<3 \mathrm{hrs}$ & 350 & 36.46 & 53 & 68.83 & 403 & 38.86 & 34.8170 & $0.0001 *$ \\
\hline & & 4-6hrs & 573 & 59.69 & 21 & 27.27 & 594 & 57.28 & & \\
\hline & & 7-9hrs & 28 & 2.92 & 1 & 1.30 & 29 & 2.80 & & \\
\hline & & $>10 \mathrm{hrs}$ & 9 & 0.94 & 2 & 2.60 & 11 & 1.06 & & \\
\hline \multirow[t]{4}{*}{7} & \multirow{4}{*}{$\begin{array}{l}\text { Accessing } \\
\text { e-books }\end{array}$} & $<3 \mathrm{hrs}$ & 331 & 34.48 & 44 & 57.14 & 375 & 36.16 & 28.6830 & $0.0001^{*}$ \\
\hline & & 4-6hrs & 581 & 60.52 & 29 & 37.66 & 610 & 58.82 & & \\
\hline & & 7-9hrs & 43 & 4.48 & 1 & 1.30 & 44 & 4.24 & & \\
\hline & & $>10 \mathrm{hrs}$ & 5 & 0.52 & 3 & 3.90 & 8 & 0.77 & & \\
\hline \multirow[t]{4}{*}{8} & \multirow{4}{*}{$\begin{array}{l}\text { Photocopyi } \\
\text { ng }\end{array}$} & $<3 \mathrm{hrs}$ & 462 & 48.13 & 55 & 71.43 & 517 & 49.86 & 15.6770 & $0.0010^{*}$ \\
\hline & & 4-6hrs & 466 & 48.54 & 21 & 27.27 & 487 & 46.96 & & \\
\hline & & 7-9hrs & 25 & 2.60 & 1 & 1.30 & 26 & 2.51 & & \\
\hline & & $>10 \mathrm{hrs}$ & 7 & 0.73 & 0 & 0.00 & 7 & 0.68 & & \\
\hline \multirow[t]{5}{*}{9} & \multirow{5}{*}{$\begin{array}{l}\text { Scanning \& } \\
\text { printing }\end{array}$} & $<3 \mathrm{hrs}$ & 420 & 43.75 & 55 & 71.43 & 475 & 45.81 & 22.1110 & $0.0001 *$ \\
\hline & & 4-6hrs & 511 & 53.23 & 21 & 27.27 & 532 & 51.30 & & \\
\hline & & 7-9hrs & 24 & 2.50 & 1 & 1.30 & 25 & 2.41 & & \\
\hline & & $>10 \mathrm{hrs}$ & 5 & 0.52 & 0 & 0.00 & 5 & 0.48 & & \\
\hline & & Total & 960 & 100.00 & 77 & 100.00 & 1037 & 100.00 & & \\
\hline
\end{tabular}

- Out of a total 1037 students, 57.57\% spend less than $3 \mathrm{hrs}$ for searching journal/magazine in which (57.60\%) of BPT Students and $(57.14 \%)$ of MPT students spend less than $3 \mathrm{hrs}$, respectively. Followed by others students spending more than $3 \mathrm{hrs}$ for same. The difference is found to be statistically significant (chi-square $=30.1370$, $\mathrm{p}=0.0001)$.

- Among 622 respondents, 59.98\% students spend less than 3hrs for searching for books, in which 575 (59.90\%) of BPT students and 47 (61.04\%) of MPT students spend less than $3 \mathrm{hrs}$, respectively. Followed by others students, spending more than $3 \mathrm{hrs}$ for same. The difference is not found to be statistically significant (chi-square $=0.3870$, $\mathrm{p}=0.9430)$. The other details are presented in Table 5 .

Table 6: Problems Faced in while Seeking Information

\begin{tabular}{|c|c|c|c|c|c|c|c|}
\hline Q13 & & Summary & BPT & MPT & Total & Z-value & P-Value \\
\hline \multirow[t]{2}{*}{1} & \multirow{2}{*}{$\begin{array}{l}\text { Needed information is } \\
\text { not available in library }\end{array}$} & Mean & 2.9 & 2.8 & 2.9 & -0.6500 & 0.5150 \\
\hline & & SD & 1.0 & 1.0 & 1.0 & & \\
\hline \multirow{2}{*}{2} & \multirow{2}{*}{$\begin{array}{l}\text { Incomplete } \\
\text { information in sources }\end{array}$} & Mean & 3.0 & 3.0 & 3.0 & -0.4510 & 0.6520 \\
\hline & & $\mathrm{SD}$ & 1.1 & 1.0 & 1.1 & & \\
\hline \multirow[t]{2}{*}{3} & \multirow{2}{*}{$\begin{array}{l}\text { Do not know how to } \\
\text { use online catalogue }\end{array}$} & Mean & 2.9 & 3.1 & 3.0 & -0.8140 & 0.4160 \\
\hline & & SD & 1.2 & 1.2 & 1.2 & & \\
\hline \multirow[t]{2}{*}{4} & \multirow{2}{*}{$\begin{array}{l}\text { Information scattered } \\
\text { in too many sources }\end{array}$} & Mean & 2.6 & 2.5 & 2.6 & -1.3920 & 0.1640 \\
\hline & & SD & 1.1 & 1.0 & 1.1 & & \\
\hline \multirow[t]{2}{*}{5} & \multirow{2}{*}{$\begin{array}{l}\text { Do not knowhow to } \\
\text { use electronic } \\
\text { resources }\end{array}$} & Mean & 3.0 & 3.0 & 3.0 & -0.1460 & 0.8840 \\
\hline & & $\mathrm{SD}$ & 1.3 & 1.4 & 1.3 & & \\
\hline \multirow[t]{2}{*}{6} & \multirow{2}{*}{$\begin{array}{l}\text { Too much information } \\
\text { on internet }\end{array}$} & Mean & 2.6 & 2.5 & 2.6 & -0.2610 & 0.7940 \\
\hline & & SD & 1.2 & 1.2 & 1.2 & & \\
\hline \multirow[t]{2}{*}{7} & \multirow{2}{*}{$\begin{array}{l}\text { Lack of information } \\
\text { skills to search }\end{array}$} & Mean & 3.0 & 3.2 & 3.0 & -1.3230 & 0.1860 \\
\hline & & $\mathrm{SD}$ & 1.2 & 1.2 & 1.2 & & \\
\hline
\end{tabular}




\begin{tabular}{|l|l|l|l|l|l|l|l|}
\hline 8 & \multirow{2}{*}{ Internet speed is slow } & Mean & 2.6 & 2.6 & 2.6 & -0.1780 & 0.8590 \\
\cline { 3 - 8 } & & $\mathrm{SD}$ & 1.2 & 1.1 & 1.2 & & \\
\hline
\end{tabular}

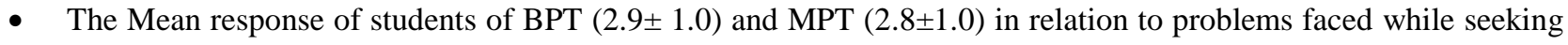
on needed information is not available in the library, which is not found to be statistically significant $(0.5150)$. It seems that the MPT Students and BPT have similar opinions.

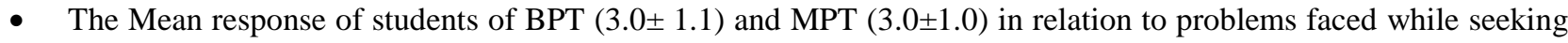
for Incomplete information in sources in the library is not found to be statistically significant $(0.6520)$. It seems that the MPT Students and BPT have similar opinions. The other details are presented in Table 6.

Table 7: Environment Affect while Seeking Information

\begin{tabular}{|l|c|c|c|c|c|}
\hline \multicolumn{1}{|c|}{ Affect } & BPT & MPT & Total & Chi-Square & P-Value \\
\hline Information overloaded & $353(36.77)$ & $29(37.66)$ & $382(36.84)$ & 0.0240 & 0.8760 \\
\hline Changing ICT environment & $82(8.54)$ & $7(9.09)$ & $89(8.58)$ & 0.0270 & 0.8690 \\
\hline Changing pattern of new syllabus & $271(28.23)$ & $33(42.86)$ & $304(29.32)$ & 7.3610 & $0.0070^{*}$ \\
\hline Cross questions raised others & $224(23.33)$ & $24(31.17)$ & $248(23.92)$ & 2.4050 & 0.1210 \\
\hline Extra work given by teachers & $329(34.27)$ & $32(41.56)$ & $361(34.81)$ & 1.6680 & 0.1960 \\
\hline $\begin{array}{l}\text { Different types of sources } \\
\text { developed in library }\end{array}$ & $156(16.25)$ & $19(24.68)$ & $175(16.88)$ & 3.6070 & 0.0580 \\
\hline Any other & $2(0.21)$ & $0(0.00)$ & $2(0.19)$ & 0.1610 & 0.6880 \\
\hline
\end{tabular}

The result of the above Table 7 represents the opinions of students with respect to the environment affecting information needs and information seeking behavior. It shows that,

- Out of a total 1037 students 382 (36.84\%) students are affected on information needs and information seeking Behavior on Information overloaded, in which 353 (36.77\%) of BPT Students and 29 (36.84\%) of MPT students are affected on information needs and information seeking Behavior. The difference is not found to be statistically significant (chi-square $=0.0240, \mathrm{p}=0.8760)$.

- A total of $89(8.58 \%)$ students are affected on information needs and information seeking Behavior on Changing ICT environment, in which $82(8.54 \%)$ of BPT students and $7(9.09 \%)$ of MPT students are affected on information needs and information seeking Behavior. The difference is not found to be statistically significant (chi-square $=0.0270, \mathrm{p}=0.8690$ ). The other details are presented in Table 7.

\section{MAJOR SUMMARY OF FINDINGS}

- A total of 1200 questionnaires were distributed to the respondents, out of which an overwhelming i.e. 1037 questionnaire were received back with a response rate $86.41 \%$.

- Among the 1037 respondents, out of which the highest 315 of them belong to 1st Year BPT (30.38\%), whereas 299 respondents belong to $2^{\text {nd }}$ Year BPT $(28.83 \%)$ and 179 respondents are from 3rd Year BPT (30.38\%) (Table 2, Page No.4).

- Out of $52.94 \%$ students, $51.25 \%$ of BPT students and $74.03 \%$ of MPT students know about the Current Developments of Reading current issues of print journals/ magazine. The majority of 536 respondents (51.69\%) students know about the Current Developments Reading latest books in the field, in which 481 (50.10\%) of BPT students and 55 (71.43\%) of MPT students know about the Current Developments. (Table 3, Page No.5). 
- The majority of 826 students (79.65\%) know about the Seek Information through Prepare the class notes, in which $765(79.69 \%)$ of BPT students and $61(79.22 \%)$ of MPT students know about the Seek Information. Whereas, the total of $714(68.85 \%)$ students know about the Seek Information through General Awareness, in which 650 $(67.71 \%)$ of BPT students and $64(83.12 \%)$ of MPT students know about the Seek Information. (Table 4, Page No.7).

\section{CONCLUSIONS}

This study has covered overall opinion of the students about reading materials, resources, ICT facilities, internet, sources and services in the library. The survey proceeded in the right direction to know about the Information Seeking Behavior of the Students and improvement in Physiotherapy College libraries in the state.

\section{REFERENCES}

1. Kumar, K,(2013). Information Seeking Behavior of Library Users in Women's Educational Institutions: A Survey. Journal of Library \& Information Science, 3 (4), pp.738-742.

2. Sakai et.al (2008).Health information seekers in Japan: a snapshot of needs, Behaviour, and recognition in 2008.Journal of the Medical Library Association,100(3), pp. 205-213.

3. Genuis, Shelagh, (2012).Constructing "sense" from evolving health information: A qualitative investigation of information seeking and sense making across sources. Journal of the Association for Information Science and Technology, 63(8), pp. 1553-1566.

4. Clarke, Martina et.al(2013).Information needs and information-seeking behaviour analysis of primary care physicians and nurses: a literature review. Health Information and Libraries Journal, 30(3), pp.178-190.

5. Sloan, Marget.al(2013). Information Seeking in Context: Results of Graduate Student Interviews. The Canadian Journal of Library and Information Practice and Research, 8(1), pp.1-18. 
